\title{
XO monosomy is associated with reduced birthweight and lowered weight gain in the mouse
}

\author{
P. S. Burgoyne, E. P. Evans* and Karen Holland
}

M.R.C. Mammalian Development Unit, 4 Stephenson Way, London NWI 2HE, and
* Sir William Dunn School of Pathology, South Parks Road, Oxford OXI 3RE, U.K.

\begin{abstract}
Summary. The growth of $\mathrm{XO}$ mice and their $\mathrm{XX}$ sisters was followed from the day of birth up to 15 weeks post partum. XO mice were underweight at birth, and grew more slowly than XX mice in the preweaning period. Some, but not all, of this decrease in growth rate was attributable to an effect of the reduced birth weight.
\end{abstract}

\section{Introduction}

Human $\mathrm{X}$ chromosome monosomy has been shown to be associated with low birth weight (Chen, Chan \& Falek, 1971; Polani, 1974) and with short stature in adults (Simpson, 1976). By contrast, $\mathrm{XO}$ mice were originally described as being normal with respect to birth weight and subsequent growth (Cattanach, 1962). Deckers (1974) and Deckers \& van der Kroon (1981) reported that growth rates were reduced in $\mathrm{XO}$ mice during the first weeks of life, but the interpretation of their results was complicated by the presence of the X-linked marker Tabby, which itself has an effect on growth, and the form of statistical analysis used was inappropriate. In addition, the XO mice used were obtained from XO mothers, and so are not strictly comparable to human XOs which are born to XX mothers.

Burgoyne \& Baker (1981a) described the results of a study on oocyte depletion in XO mice in which the XO mice were obtained from XX mothers, and were identified by karyotyping, thus avoiding the use of an X-linked marker such as Tabby. Weight data obtained incidental to this oocyte study (Burgoyne \& Baker, 1981b) revealed that 12- and 25-day-old XO mice were significantly smaller than their XX sisters. The present study extends these observations by providing growth data for groups of XO and XX mice from birth up to a maximum of 15 weeks post partum.

\section{Materials and Methods}

The litters of mice used in this study were derived as follows. Firstly, males carrying the $\mathrm{X}$ inversion In $(X) 1 H$ (Evans \& Phillips, 1975) were mated to outbred albino females of the Schofield (S. Schofield \& Co., Delph, Lancs, U.K.) or MF 1 (Olac, Oxford, U.K.) strain. The heterozygous $\operatorname{In}(\mathrm{X}) / \mathrm{X}$ female offspring were subsequently mated to albino males (of the maternal strain), to produce litters in which about $25 \%$ of the females are XO (Phillips, Hawker \& Moseley, 1973). Males were culled at birth. Weaning was always at 3 weeks and the females of each litter were caged together. Food and water were supplied ad libitum.

The females were weighed on the day of birth and subsequently at weekly intervals up to a maximum of 15 weeks, using a Mettler $1200 \mathrm{~N}$ top pan balance. On some occasions 2- and 3-weekold mice had to be etherized to obtain an accurate weight reading. 
At the end of the weighing period the mice were killed and were karyotyped from bone marrow metaphase spreads. In about half the litters, trypsin-Giemsa banding (Papaioannou, Evans, Gardner \& Graham, 1979) was used to identify those females that carried the inversion (half of the $\mathrm{XX}$ females are expected to do so).

\section{Results}

Because there are major litter effects on birth weight and subsequent growth, all comparisons have been made on a within-litter basis. The 'Schofield' data and 'MF1' data have been analysed separately because the magnitude of the effects observed appeared to vary with genetic background. There were no significant differences in birth weight or growth rate between $\mathrm{XX}$ females with and without the inversion, and the inversion has therefore been ignored when making $\mathrm{XO}-\mathrm{XX}$ comparisons.

The mean weights for $\mathrm{XO}$ and $\mathrm{XX}$ mice from 0 to 15 weeks for the two crosses are given in Table 1. When these data were plotted it was found that the growth curves for the $\mathrm{XO}$ and $\mathrm{XX}$ mice from both crosses were very similar in shape, and could be conveniently broken down into three growth phases: 0-3 weeks (phase 1), 3-5 weeks (phase 2) and 5-14 weeks (phase 3). The mean weighted $\mathrm{XO}-\mathrm{XX}$ differences (Text-fig. 1) showed that XO mice from both crosses were smaller on average than their XX sisters throughout the period studied.

Table 1. Mean \pm s.e.m. weights for XO and XX mice for the period 0 15 weeks post partum

\begin{tabular}{|c|c|c|c|c|}
\hline \multirow{3}{*}{$\begin{array}{c}\text { Weeks } \\
\text { post partum }\end{array}$} & \multicolumn{4}{|c|}{ Litter weight means (g) } \\
\hline & \multicolumn{2}{|c|}{ MF1 cross* } & \multicolumn{2}{|c|}{ Schofield cross $\dagger$} \\
\hline & XO & $\mathrm{XX}$ & $\mathrm{XO}$ & $\mathrm{XX}$ \\
\hline 0 & $1.68 \pm 0.05$ & $1.72 \pm 0.04$ & $1.54 \pm 0.12$ & $1.61 \pm 0.06$ \\
\hline 1 & $5.80 \pm 0.18$ & $6.00 \pm 0.16$ & $5.55 \pm 0.47$ & $6.00 \pm 0.20$ \\
\hline 2 & $9.58 \pm 0.40$ & $9.89 \pm 0.37$ & $9.59 \pm 0.67$ & $10.10 \pm 0.51$ \\
\hline 3 & $13.71 \pm 0.40$ & $14.49 \pm 0.35$ & $13.10 \pm 0.53$ & $14.15 \pm 0.40$ \\
\hline 4 & $18.94 \pm 0.62$ & $20.05 \pm 0.53$ & $19.41 \pm 1.03$ & $21.04 \pm 0.54$ \\
\hline 5 & $23.82 \pm 0.50$ & $24.48 \pm 0.41$ & $22.80 \pm 1.47$ & $23.93 \pm 0.98$ \\
\hline 6 & $25.58 \pm 0.44$ & $25.89 \pm 0.48$ & $23.65 \pm 0.94$ & $25.17 \pm 0.56$ \\
\hline 7 & $26.73 \pm 0.53$ & $27.33 \pm 0.44$ & $24.92 \pm 1.06$ & $26.01 \pm 0.59$ \\
\hline 8 & $27.62 \pm 0.68$ & $28.84 \pm 0.55$ & 二 & - \\
\hline 9 & $29.60 \pm 0.71$ & $29.82 \pm 0.93$ & - & - \\
\hline 10 & $30.43 \pm 0.74$ & $30.97 \pm 0.86$ & $26.98 \pm 1.48$ & $28.71 \pm 0.65$ \\
\hline 11 & $31 \cdot 12 \pm 0.63$ & $31.68 \pm 1.00$ & - & - \\
\hline 12 & $31.33 \pm 0.57$ & $32.33 \pm 1.06$ & - & - \\
\hline 13 & $32.89 \pm 0.85$ & $33.87 \pm 1.09$ & - & - \\
\hline 14 & $33.28 \pm 0.85$ & $34.93 \pm 1.17$ & $30.54 \pm 1.17$ & $32.63 \pm 0.80$ \\
\hline 15 & $33.50 \pm 1.12$ & $34.40 \pm 1.43$ & $30.63 \pm 1 \cdot 10$ & $32.72 \pm 1.02$ \\
\hline
\end{tabular}

* 12 litters with $19 \mathrm{XO}$ and $48 \mathrm{XX}$ mice at $0-8$ weeks and a subset of 8 litters with $12 \mathrm{XO}$ and $36 \mathrm{XX}$ mice at $9-15$ weeks.

+4 litters with $9 \mathrm{XO}$ and $12 \mathrm{XX}$ mice.

The analysis of the data has been approached as follows. First, we have asked whether the initial samples of XO mice have a lower birth weight than their XX sisters. Testing the mean weighted difference within litters against the standard error (s.e.m.) of the difference (MF1 cross: $-0.06 \pm 0.03$; Schofield cross: $-0.11 \pm 0.03$ ) gave $t_{43}=1.885, P=0.05-0.025$ for the MF1 cross and $t_{13}=4.007, P=0.0025-0.0005$ for the Schofield cross. XO mice were therefore significantly underweight at birth. 


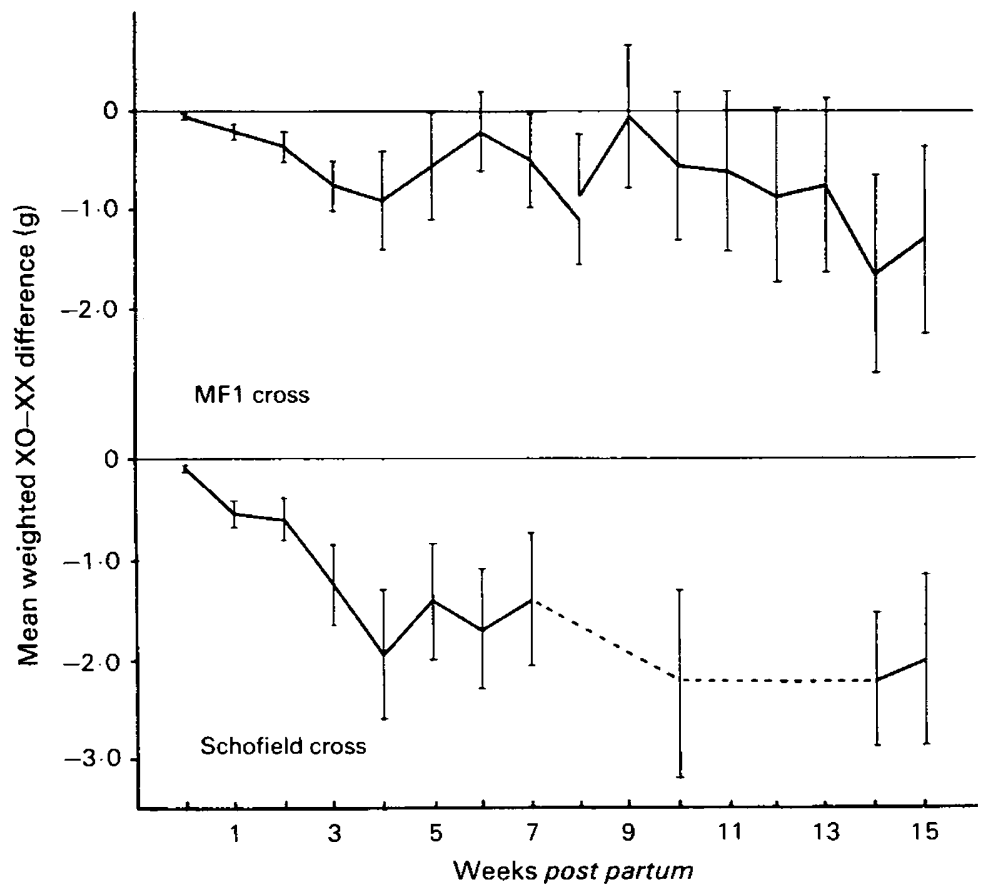

Text-fig. 1. Estimates of the mean \pm s.e.m. difference in weight between $X O$ and $X X$ mice for the MF1 and Schofield crosses from 0 to 15 weeks post partum. Note the large increase in the standard errors between 0 and 4 weeks. For the MF1 cross the $0-8$-week period is represented by data from 12 litters, and from $8-15$ weeks by a subset of 8 litters, and for the Schofield cross by data from 4 litters. The shape of the curve is similar in the two crosses, but the XO-XX difference is greater in the Schofield cross.

We then asked whether growth rates differ between XO and XX mice. Regression lines were fitted to the three phases (0-3, 3-5 and 5-14 weeks) of the growth curves for individual mice, and the slopes of these regression lines, which estimate weekly weight gain, were analysed to show whether within-litter differences between $\mathrm{XO}$ and XX mice were significant for any of the three phases (Table 2). For both crosses XO mice grew significantly more slowly than did XX mice during phase 1 , but there were no significant differences in growth rate during phases 2 and 3 .

It seemed from an inspection of the data for XX mice that phase-1 growth rates were positively

Table 2. Estimates of mean \pm s.e.m. weekly weight gain and weighted $\mathrm{XO}-\mathrm{XX}$ difference for $\mathrm{XO}$ and $\mathrm{XX}$ mice in growth phases 1 (0-3 weeks), 2 (3-5 weeks) and 3 (5-14 weeks)

\begin{tabular}{|c|c|c|c|c|c|c|}
\hline \multirow{3}{*}{$\begin{array}{l}\text { Growth } \\
\text { phase }\end{array}$} & \multicolumn{3}{|c|}{ MF1 cross } & \multicolumn{3}{|c|}{ Schofield cross } \\
\hline & \multicolumn{2}{|c|}{ Weekly wt gain $(\mathrm{g})^{*}$} & \multirow{2}{*}{$\begin{array}{c}\text { Weighted } \\
\text { XO-XX } \\
\text { difference }(g) \dagger\end{array}$} & \multicolumn{2}{|c|}{ Weekly wt gain $(\mathrm{g})^{*}$} & \multirow{2}{*}{$\begin{array}{c}\text { Weighted } \\
\text { XO-XX } \\
\text { difference }(\mathrm{g}) \dagger\end{array}$} \\
\hline & XO & $\mathrm{XX}$ & & xo & $\mathrm{XX}$ & \\
\hline 1 & $3.99 \pm 0.13$ & $4 \cdot 23 \pm 0$. & $-0.24 \pm$ & $3.87 \pm$ & $4 \cdot 17 \pm$ & $-0.35 \pm 0.12 \ddagger$ \\
\hline 2 & $5 \pm 0.16$ & $4.99 \pm 0.16$ & $+0.09 \pm 0.22$ & $4.85 \pm 0$ & $4.89 \pm 0$ & $-0.07 \pm 0.20$ \\
\hline 3 & $0.98 \pm 0.06$ & $1.09 \pm 0.07$ & $-0.10 \pm 0.07$ & $0.85 \pm 0.07$ & $0.95 \pm 0.06$ & $-0.09 \pm 0.05$ \\
\hline
\end{tabular}

* Means of litter means.

$\dagger$ The mean weighted difference $\frac{\sum w d}{\sum w}$, where $d$ is the XO-XX difference for a litter, and $w=\frac{n_{1} n_{2}}{n_{1}+n_{2}}\left(n_{1}\right.$ and $\mathrm{n}_{2}$ are the numbers of $\mathrm{XO}$ and $\mathrm{XX}$ mice in the litter).

$\ddagger$ These differences are significant: $t$ test (one-tailed) gives $P=0 \cdot 02-0 \cdot 01$. 
correlated within litters with birth weights. If this were so, then the reduced initial growth rate of XOs might be attributable to their below-normal birth weights. Accordingly, a pooled estimate from within litters of the regression of phase-1 growth rate on birth weight was calculated from all the XX data available for the MF1 cross (this included data from 9 litters in which there were no XO females). This regression was significant $\left(t_{66}=2 \cdot 816, P=0.01-0.005\right)$ and gave an estimate that a birth weight advantage of $0.1 \mathrm{~g}$ increased phase- 1 weekly weight gain by $0.091 \mathrm{~g}$.

When the XO data for birth weight and phase-1 growth rate were plotted as deviations from their corresponding XX litter means (Text-fig. 2) 15 out of the 19 XO mice from the MF1 cross and 7 out of the 9 XO mice from the Schofield cross fell below the regression line predicted from the XX data. This means that the growth rate of XO mice from 0 to 3 weeks is even lower than would be predicted from their low birth weights.

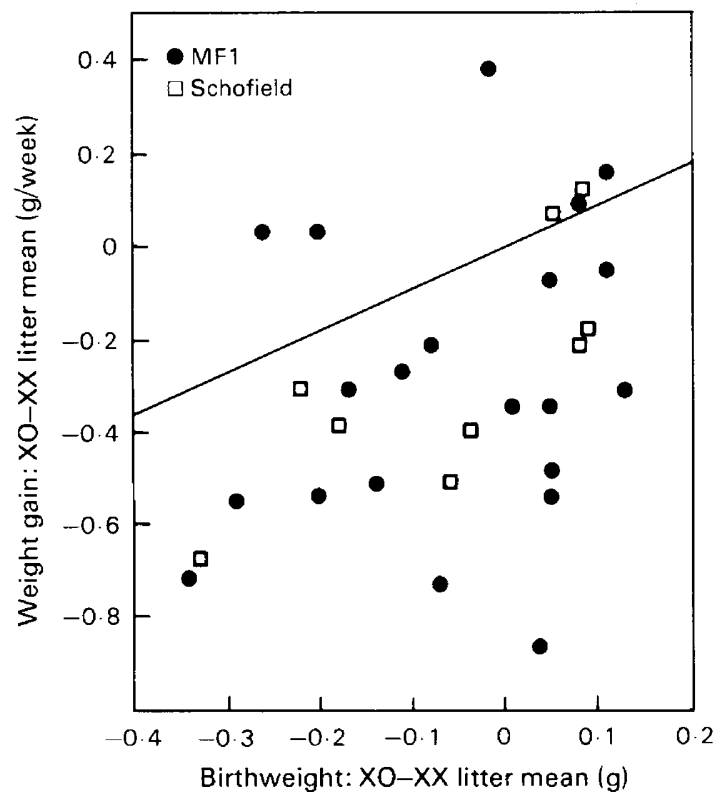

Text-fig. 2. The relationship for $X O$ mice between birth weight and weekly weight gain during phase 1 . The diagonal line gives the relationship predicted from XX data. For the MF1 cross and Schofield cross $\mathrm{XO}$ mice tend to have a lower weight gain in relation to their birth weight than do XX mice.

\section{Discussion}

The results demonstrate that XO mice (obtained from XX mothers) have a lower birth weight and a decreased weight gain before weaning when compared with their XX sisters. After weaning XO growth rates appear to be normal, but the earlier weight deficit is not made up. These results confirm and extend those of Deckers \& van der Kroon (1981) who reported that XO mice (born to XO mothers) have a reduced growth rate during the first weeks of life. In the present study part of the reduced growth rate could be attributed to the reduced birth weight, since a clear effect of birth weight on preweaning growth was found for $\mathrm{XX}$ mice. This effect of birth weight might operate through competition between sibs for milk. Nevertheless, part of the reduced growth of XO mice was not attributable to this cause, and presumably reflects a difference in the physiology of the two genotypes. Deckers \& van der Kroon (1981) have in fact reported that XO mice have reduced thyroid activity and a lowered body temperature.

Ohno's thesis (1969) that the X-chromosome of mammals has been conserved during evolution has received much experimental support (see Shows, 1979), and it is therefore reasonable to equate the growth deficiencies of the XO mouse with those associated with human XO monosomy. Human 
XO individuals are underweight at birth (Chen et al., 1971; Polani, 1974), and detailed studies of their subsequent growth (Lemli \& Smith, 1963; Brook, Mürset, Zachman \& Prader, 1974) demonstrate that growth rate is reduced during childhood and that the pubertal growth spurt of normal girls is absent. XO girls continue growing beyond the age at which maximum height is attained in normal girls, but their final height is well below the norm (see Simpson, 1976).

The only clear difference between the effect of XO monosomy on growth in the two species concerns growth during puberty, which is affected in the human but not in the mouse. There may in fact be no pubertal growth spurt in normal mice. Certainly, bilateral ovariectomy at 8 days post partum has no effect on subsequent growth (P. S. Burgoyne, unpublished observations). The absence of a pubertal growth spurt in XO girls is probably related to the lack of ovarian oestrogens although this is a matter of some debate (see Tanner, 1981; Brook, 1981). Evidence against the involvement of oestrogens is the finding that their administration does not increase the final height attained by XO patients, although there is a transitory increase in growth rate (Lev-Ran, 1977). However, there is no evidence that the pubertal growth spurt of normal girls contributes to their final height, and it may be that there is a 'target height' which is independent of puberty, and that ovarian steroids merely hasten its attainment.

If the growth defects associated with XO monosomy are equivalent in mouse and man, then the XO mouse can be used to study their aetiology. In a parallel study (Burgoyne, Tam \& Evans, 1983) the growth deficiencies of XO mice have been shown to have their origins in a marked developmental retardation in early pregnancy.

E.P.E. is a member of the M.R.C. external staff.

\section{References}

Brook, C.G.D. (1981) Endocrinological control of growth at puberty. Br. med. Bull. 37, 281-285.

Brook, C.G.D., Mürset, G., Zachman, M. \& Prader, A. (1974) Growth in children with 45,XO Turner's syndrome. Archs Dis. Childh. 49, 789-795.

Burgoyne, P.S. \& Baker, T.G. (1981a) Oocyte depletion in XO mice and their XX sibs from 12 to 200 days post partum. J. Reprod. Fert. 61, 207-212.

Burgoyne, P.S. \& Baker, T.G. (1981 b) The XO ovarydevelopment and function. In Development and Function of Reproductite Organs, pp. 122-128. Eds A. G. Byskov \& H. Peters. Excerpta Medica, Amsterdam.

Burgoyne, P.S., Tam, P.P.L. \& Evans, E.P. (1983) Retarded development of XO conceptuses during early pregnancy in the mouse. $J$. Reprod. Fert. 68, 387-393.

Cattanach, B.M. (1962) XO mice. Genet. Res. 3, 487-490.

Chen, A.T.L., Chan, Y.-K. \& Falek, K. (1971) The effects of chromosome abnormalities on birth weight in man. I. Sex chromosome disorders. Hum. Hered. 21, $543-556$

Deckers, J.F.M. (1974) Some characteristics of the XO mouse (Mus musculus L.). 110 pp. Ph.D. thesis, Roman Catholic University of Nijmegen.

Deckers, J.F.M. \& van der Kroon, P.H.W. (1981) Some characteristics of the XO mouse (Mus musculus L.). I. Vitality: growth and metabolism. Genetica 55, 179185.

Evans, E.P. \& Phillips, R.J.S. (1975) Inversion heterozygosity and the origin of XO daughters of $\mathrm{Bpa} /+$ female mice. Nature, Lond. 256, 40-41.

Lemli, L. \& Smith, D.W. (1963) The XO syndrome: a study of the differentiated phenotype in 25 patients. J. Pediat. 63, 577-588.
Lev-Ran, A. (1977) Androgens, estrogens, and the ultimate height in $\mathrm{XO}$ gonadal dysgenesis. Am. J. Dis. Child. 131, 648-649.

Ohno, S. (1969) Evolution of sex chromosomes in mammals. A. Rev, Genet. 3, 495-524.

Papaioannou, V.E., Evans, E.P., Gardner, R.L. \& Graham, C.F. (1979) Growth and differentiation of an embryonal carcinoma cell line (c1456). J. Embryol. exp. Morph. 54, 277-295.

Phillips, R.J.S., Hawker, S.G. \& Moseley, H.J. (1973) Bare-patches, a new sex-linked gene in the mouse, associated with a high proportion of XO females. I. A preliminary report of breeding experiments. Genet. Res. 22, 91-99.

Polani, P.E. (1974) Chromosomal and other genetic influences on birth weight variation. In Size at Birth (Ciba Fdn Symp. No. 27 (new series)), pp. 127-164. Eds K. Elliott \& J. Knight. Elsevier/Excerpta Medica/North Holland, Amsterdam.

Shows, T.B. (1979) The $X$ chromosome gene map. In Genetic Mechanisms of Sexual Development, pp. 253269. Eds H. L. Vallet \& 1. H. Porter. Academic Press, New York.

Simpson, J. L. (1976) Disorders of Sexual Differentiation-Etiology and Clinical Delineation. Academic Press, New York.

Tanner, J.M. (1981) Postnatal growth of gonads and genital tracts, and the development of secondary sex characteristics. In Mechanisms of Sex Differentiation in Animals and Man, pp. 385-420. Eds C. R. Austin \& R. G. Edwards. Academic Press. London.

\section{Received 11 November 1982}

